\title{
Degradation of Endogenous Bacterial Cell Wall Polymers by the Muralytic Enzyme Mutanolysin Prevents Hepatobiliary Injury in Genetically Susceptible Rats with Experimental Intestinal Bacterial Overgrowth
}

\author{
S. N. Lichtman, * E. E. Okoruwa, * J. Keku, * J. H. Schwab, ${ }^{*}$ and R. B. Sartor \\ Departments of ${ }^{*}$ Pediatrics, ${ }^{\ddagger}$ Microbiology and Immunology, and ${ }^{\S}$ Medicine and Core Center for Gastrointestinal Biology and Disease, \\ University of North Carolina, Chapel Hill, North Carolina 27599-7220
}

\begin{abstract}
Jejunal self-filling blind loops with subsequent small bowel bacterial overgrowth (SBBO) induce hepatobiliary injury in genetically susceptible Lewis rats. Lesions consist of portal tract inflammation, bile duct proliferation, and destruction. To determine the pathogenesis of SBBO-induced hepatobiliary injury, we treated Lewis rats with $\mathrm{SBBO}$ by using several agents with different mechanisms of activity. Buffer treatment, ursodeoxycholic acid, prednisone, methotrexate, and cyclosporin $A$ failed to prevent SBBO-induced injury as demonstrated by increased plasma aspartate aminotransferase (AST) and elevated histology scores. However, hepatic injury was prevented by mutanolysin, a muralytic enzyme whose only known activity is to split the $\beta$ 1-4 N-acetylmuramyl- $N$-acetylglucosamine linkage of peptidoglycan-polysaccharide (PG-PS), a bacterial cell wall polymer with potent inflammatory and immunoregulatory properties. Mutanolysin therapy started on the day blind loops were surgically created and continued for 8 wk significantly diminished AST (101 $\pm 37 \mathrm{U} /$ liter) and liver histology scores (2.2 \pm 2.7$)$ compared to buffer-treated rats $(228 \pm 146 \mathrm{U} /$ liter, $P<0.05,8.2 \pm 1.9, P<0.001$ respectively). Mutanolysin treatment started during the early phase of hepatic injury, 16-21 d after surgery, decreased AST in 7 of 11 rats from $142 \pm 80$ to $103 \pm 24 \mathrm{U} /$ liter contrasted to increased AST in 9 of 11 buffertreated rats from $108 \pm 52$ to $247 \pm 142 \mathrm{U} /$ liter, $P<0.05$. Mutanolysin did not change total bacterial numbers within the loop, eliminate Bacteroides sp., have in vitro antibiotic effects, or diminish mucosal PG-PS transport. However, mutanolysin treatment prevented elevation of plasma anti-PG antibodies and tumor necrosis factor- $\alpha$ (TNF $\alpha)$ levels which occurred in buffer treated rats with SBBO and decreased TNF $\alpha$ production in isolated Kupffer cells stimulated in vitro with PG-PS. Based on the preventive and therapeutic activity of this highly specific muralytic enzyme, we conclude that systemic uptake of PG-PS derived from endogenous enteric bacteria contributes to hepatobiliary injury induced by SBBO in susceptible rat strains. ( $J$. Clin. Invest. 1992. 90:1313-1322.) Key words: bacterial cell wall polymers $\bullet$ Kupffer cells • muramidase • peptidoglycan-polysaccharide • sclerosing cholangitis • tumor necrosis factor
\end{abstract}

Address reprint requests to Dr. Lichtman, Room 310, Burnett Womack Building, CB 7220, Department of Pediatric Gastroenterology, University of North Carolina, Chapel Hill, NC 27599-7220.

Received for publication 15 August 1991 and in revised form 14 February 1992.

J. Clin. Invest.

(C) The American Society for Clinical Investigation, Inc. $0021-9738 / 92 / 10 / 1313 / 10 \quad \$ 2.00$

Volume 90, October 1992, 1313-1322

\section{Introduction}

We previously reported that inbred Lewis and Wistar rats with experimental small bowel bacterial overgrowth (SBBO) ${ }^{1}$ develop hepatobiliary injury, but Buffalo and Fischer rats with identical bacterial concentrations fail to exhibit hepatic inflammation (1-4). SBBO rapidly develops after surgical creation of jejunal self-filling blind loops (SFBL), which contain a complex milieu of predominantly anaerobic enteric bacteria, bacterial products such as endotoxin (lipopolysaccharide, LPS), formylated oligopeptides (FMLP) and peptidoglycan-polysaccharide (PG-PS), deconjugated bile salts, and other potentially toxic metabolites. Previous studies indicated that bacterial infection of liver, spleen, peritoneum, cardiac blood, and portal vein blood did not occur ( 1 ). Translocation of bacteria to mesenteric lymph nodes was frequent in both susceptible and resistant rat strains with SBBO, but did not correlate with development of hepatobiliary injury (1). Anaerobic bacteria or their products were incriminated in the pathogenesis of this model by prevention of experimental hepatobiliary inflammation with metronidazole and tetracycline (2). Gentamicin and polymyxin B failed to prevent injury indicating that gram-negative aerobic organisms and LPS were not likely the cause (2).

The present study is designed to determine the mechanism by which jejunal overgrowth of anaerobic bacteria causes hepatobiliary injury in susceptible rat strains. One possible mechanism is derived from the observation that SBBO produces abnormal bile acids which may be toxic to the liver (5). Ursodeoxycholic acid diminishes hepatic injury as measured by serum enzymes in a variety of cholestatic liver diseases presumably by its effect on the bile salt pool (6). Alternatively, to probe for a possible immune-mediated mechanism of disease, we used cyclosporin A, prednisone, and methotrexate treatment of rats with SBBO. A third potential mechanism involves toxic, immunogenic, persistent bacterial products derived from the intestinal lumen. The inability of polymyxin B, which binds LPS (7), to prevent hepatobiliary injury (2) provides evidence that bacterial LPS does not play a major role in the pathogenesis of injury. Other bacterial cell wall polymers, however, such as PG-PS have immunomodulating and pro-inflammatory properties (8) that make them logical candidates to contribute to hepatobiliary inflammation associated with experimental SBBO.

1. Abbreviations used in this paper: AST, aspartate aminotransferase; BHI, brain-heart infusion; GBSS, Gey's balanced salt solution; PG-PS, peptidoglycan-polysaccharide; PG-APS, PG-PS purified from group A streptococci; SBBO, small bowel bacterial overgrowth; SEBL and SFBL, self-emptying and self-filling blind loops; TNF $\alpha$, tumor necrosis factor- $\alpha$. 
PG-PS polymers are ubiquitous in the distal intestinal lumen in that they are a structural component of cell walls of nearly all bacteria including the normal intestinal flora. The structure of PG from most bacteria is essentially similar, although there are important differences in detail and immunodominant epitopes $(8,9)$. We have utilized the PG-PS purified from group A streptococci (PG-APS) as our standard cell wall preparation in studies of host response to defined bacterial cell wall polymers. Systemic injection of PG-APS produces hepatic granulomas (10), chronic erosive polyarthritis (11), and uveitis (12) in genetically susceptible rats, whereas subserosal (intramural) injection of PG-APS produces chronic spontaneously relapsing enterocolitis with hepatic granulomas, arthritis, and anemia (13). PG-PS derived from normal enteric flora also can cause chronic joint $(14,15)$ and intestinal inflammation. Rats with experimental SBBO have elevated plasma and luminal anti-PG antibodies compared with sham-operated rats and rats with self-emptying blind loops (SEBL), which serve as surgical controls (3). After instillation of PG-APS into the jejunum, PG-APS absorption and hepatic accumulation of PGAPS is increased in rats with SBBO compared to sham-operated controls (3). Previous studies showed that PG-APS is concentrated within Kupffer cells, where it remains for at least 3 mo after intraperitoneal injection (16). Together, these data indicate that PG-PS can be absorbed from the intestinal lumen and be deposited in the liver and indirectly incriminate PG-PS from luminal bacteria in the pathogenesis of hepatobiliary inflammation associated with SBBO. We hypothesize that PGPS derived from anaerobic bacteria proliferating within the blind loop is absorbed, transported to the liver, and phagocytosed by the Kupffer cells which then produce proinflammatory cytokines, such as tumor necrosis factor- $\alpha$ (TNF $\alpha)$ and other mediators leading to hepatobiliary injury in genetically susceptible rats.

PG-PS polymers from certain bacterial strains, for example, group A streptococci, are highly resistant to degradation by lysozyme (17-19) and therefore persist within macrophages for long periods of time (16). This may explain the chronicity of inflammation induced by certain forms of PG-PS such as PG-APS. Easily degradable PG-PS polymers induce less chronic inflammation (17-19). Mutanolysin, an enzyme derived from Streptomyces globisporus, splits the $\beta$ 1-4 linkage of $N$-acetylmuramyl- $N$-acetylglucosamine in the glycan backbone of the PG-PS polymer, a linkage which is highly conserved among bacterial species $(8,20)$. This muralytic enzyme has the same specificity as tissue lysozyme but has a wider range of activity among PG-PS from bacterial strains resistant to lysozyme, such as PG-APS (17-19). After in vitro or in vivo degradation of the PG-PS polymer by mutanolysin, chronic inflammation is not sustained. Mutanolysin abrogated the chronic arthritis, granulomatous hepatitis (21), and enterocolitis (22) induced by PG-APS. Because the only known function of mutanolysin is to cleave the $\beta$ 1-4 linkage of peptidoglycan, this molecule is used in the present study as a tool to directly study the role of endogenous PG-PS derived from normal intestinal flora in the pathogenesis of hepatobiliary injury associated with SBBO. This muralytic agent is compared with ursodeoxycholic acid and several immunosuppressive agents in prevention of hepatobiliary inflammation to define pathogenic mechanisms in this model.

\section{Methods}

Surgical procedures. 10-cm SFBL were created in the jejunum 8-10 $\mathrm{cm}$ distal to the ligament of Treitz in an antiperistaltic direction using sterile technique and ether anesthesia as described previously (23). SBBO develops within $1 \mathrm{wk}$, rapidly reaching $10^{8-10}$ predominantly anaerobic bacterial organisms per milliliter of luminal contents after SFBL surgery (24). Surgical controls consisted of sham-operated rats that had a laparotomy but no intestinal anastomosis and rats with SEBL in which the loops were constructed in an isoperistaltic fashion to empty continuously (1). Although rats with SEBL have a slight increase (2-3 logs CFU/ml) in bacteria, manifestations of SBBO do not develop (24).

Experimental design. Inbred female Lewis rats (Charles River Breeding Laboratories, Raleigh, NC) weighing 150-175 g were used because they develop hepatobiliary injury within the shortest time period (only 3-8 wk) after experimental SBBO compared with other rat strains examined to date (1). After an overnight fast, SFBL were constructed and drug treatments were started according to the following protocol. Groups of 6-10 rats received one of the following drugs dissolved in their drinking water beginning $24 \mathrm{~h}$ after surgery and continuing until the end of the experiment: cyclosporin A (Sandoz Inc., East Hanover, NJ; $15 \mathrm{mg} / \mathrm{kg}$ per d), prednisone (Smith Kline \& French, Philadelphia, PA; $2 \mathrm{mg} / \mathrm{kg}$ per d), or methotrexate (Lederle Laboratories, Wayne, $\mathrm{NJ} ; 0.075 \mathrm{mg} / \mathrm{kg}$ three times per week). Drugs were added daily to a $50-\mathrm{ml}$ volume so that consumption of $20 \mathrm{ml}$ would contain an entire daily dose. The volume of drinking water consumed was monitored and rats drank $20-30 \mathrm{ml}$ daily. Ursodeoxycholic acid (CIBA-Geigy Corp., Summit, NJ; $15 \mathrm{mg} / \mathrm{kg}$ per d) was given daily by gavage feeding in a $1.5-\mathrm{ml}$ volume. Cyclosporin A (Sandoz Inc.) was also given i.m. $20 \mathrm{mg} / \mathrm{kg}$ per d using a dose previously shown to prevent PG-APS-induced systemic inflammation (25). Mutanolysin (Sigma Chemical Co., St. Louis, MO) was administered intravenously by tail vein, $200 \mu \mathrm{g}$ in $200 \mu \mathrm{l}$ of buffer three times per week in groups of 4-11 rats starting $(a)$ within $24 \mathrm{~h}$ of SFBL surgery continuing for 4 or 8 wk to determine its ability to prevent hepatobiliary inflammation, $(b)$ 16-21 d after SFBL surgery continuing for 8-10 wk to measure its therapeutic efficacy in early hepatobiliary inflammation, $(c)$ 33-53 days after SFBL surgery continuing for 8-10 wk to determine its ability to reverse advanced hepatobiliary injury. Mutanolysin was dissolved in $0.1 \mathrm{M}$ potassium phosphate buffer, $\mathrm{pH} 6.2$, and frozen in aliquots of 1 $\mathrm{mg} / \mathrm{ml}$ solution which were used within $3 \mathrm{~d}$. Control rats were treated with $200 \mu \mathrm{l}$ of $0.1 \mathrm{M}$ potassium phosphate buffer, $\mathrm{pH} 6.2$, or heat-inactivated mutanolysin. Heat-inactivated mutanolysin was boiled for 15 min immediately before use (20) and confirmed to be inactive by lack of degradation of sonicated PG-APS over $48 \mathrm{~h}$ as measured by lack of change of optical density at $600 \mathrm{~nm}$.

All rats were weighed weekly. When rats were killed, cardiac blood, peritoneal cavity fluid, liver, spleen, and mesenteric lymph nodes were anaerobically cultured as described below. Specimens of liver were fixed in $10 \%$ buffered formalin, then processed for histological examination and stained using hematoxylin and eosin and periodic acid-Schiff diastase-digested techniques. Blood was drawn from the tail vein before surgery, periodically throughout the experiments and by cardiac puncture when rats were killed to measure plasma aspartate aminotransferase (AST) and TNF $\alpha$.

Histologic score. Histologic slides were interpreted by one observer in a blinded randomized manner using a system of five parameters which was previously described (1). Normal histology scores are 0-4 and abnormal histology scores are 5-11.

Bacterial culture of organs. A modification of the technique used by Berg (26) was used as described previously (1-3). By using sterile instruments, the abdominal cavity was opened, and a peritoneal culture was obtained by swabbing the viscera with a sterile cotton-tipped applicator stick. Specimens of liver, spleen, and mesenteric lymph nodes were excised, weighed, and homogenized using $0.4-0.7 \mathrm{~g} / \mathrm{ml}$ of brain- 
heart infusion (BHI) for liver and spleen and $0.04-0.07 \mathrm{~g} / \mathrm{ml}$ of BHI for mesenteric lymph nodes. All specimens were inoculated on prereduced BHI agar plates which were cultured anaerobically in BBL Gas Pak Jars (Becton Dickinson \& Co., Cockeysville, MD) at $37^{\circ} \mathrm{C}$ for at least $72 \mathrm{~h}$.

Bacterial cultures of luminal contents. As previously described (1), $10 \mathrm{ml}$ of iced saline was flushed through the loop. The fluid was collected, homogenized, diluted serially in BHI from $10^{-1}$ to $10^{-10}$, and cultured anaerobically.

Blind loop contents were isolated from rats treated with mutanolysin in order to confirm the presence of Bacteroides sp. Blind loop contents were initially diluted serially from $10^{-1}$ to $10^{-10}$ and then cultured on phenyl ethyl alcohol plates. These plates inhibit the growth of Escherichia coli and other coliform species and increase the recovery of $\mathrm{BaC}$ teroides sp. After $72 \mathrm{~h}$, individual colonies from plates with dilutions $10^{-7}$ to $10^{-10}$ were subcultured both aerobically and anaerobically. After another 72-h incubation, obligate anaerobes were gram stained. All obligate anaerobic gram negative rods were subsequently identified using the Minitek system (Becton Dickinson \& Co.).

To directly test for a possible antibiotic effect of mutanolysin, enteric bacteria from six different rats were cultured in the presence and absence of mutanolysin. $100 \mu \mathrm{g}$ of mutanolysin in a $10-\mu \mathrm{l}$ volume or 10 $\mu \mathrm{l}$ of saline alone, were added directly to aliquots of blind loop contents diluted $10^{-7}$ to $10^{-10}$ as they were spread onto BHI culture plates. BHI agar plates were cultured anaerobically for at least $72 \mathrm{~h}$ and colonyforming units were counted in each group.

Anti-PG antibodies. Anti-PG IgA, IgG, and IgM antibodies were assayed by ELISA in plasma samples taken before surgery and when rats were killed. Formamide-extracted PG was purified from Streptococcus pyogenes group A, type 3 , strain D58 as previously described (27) and microtiter wells were coated with $2 \mu \mathrm{g} / \mathrm{ml}$ in phosphate-buffered saline (PBS). After incubation for $15 \mathrm{~h}$ at $4^{\circ} \mathrm{C}$, microtiter wells were washed three times with PBS-Tween $(0.5 \%)$. After unbound sites were blocked with $0.5 \%$ bovine serum albumin, samples or immunoglobulin standards were incubated for $8 \mathrm{~h}$ at $25^{\circ} \mathrm{C}$. Subsequently, affinity-purified anti-rat IgG or IgM antibody, which was conjugated to alkaline phosphatase (Sigma Chemical Co.), was applied for $15 \mathrm{~h}$ at $4^{\circ} \mathrm{C}$. Affinity purified anti-rat IgA and anti-rat-IgA conjugated to alkaline phosphatase were prepared as described below. Color developed in the presence of a $p$-nitrophenyl substrate (tablets [ $5 \mathrm{mg} / \mathrm{ml}$ ]; Sigma Chemical Co.) and the results were read with an ELISA reader at an optical density of $405 \mathrm{~nm}$. The standard curve for IgA ranged from 0 to $15 \mathrm{ng} / \mathrm{ml}$, for $\mathrm{IgG}$ from 0 to $25 \mathrm{ng} / \mathrm{ml}$, and for $\mathrm{IgM}$ for 0 to $500 \mathrm{ng} / \mathrm{ml}$; and color reaction time was $90 \mathrm{~min}$.

Preparation of anti-rat IgA and the alkaline phosphatase conjugate. To produce affinity-purified anti-rat IgA, rat IgA was purified from bile in order to create an affinity column. Rat bile was collected on ice in the presence of $5 \mathrm{mM}$ sodium EDTA, $500 \mathrm{KIU} / \mathrm{ml}$ aprotinin, and $0.5 \mathrm{mM}$ phenylmethylsulfonyl fluoride. A $20-\mathrm{ml}$ sample of bile was loaded onto a Sephadex G-75 column $(116 \times 2.2 \mathrm{~cm})$, and eluted with PBS. The void volume fraction was applied to a Sepharose 6B column $(116 \times 2.2 \mathrm{~cm})$ and eluted with PBS. IgA fractions were identified by immunodiffusion, pooled, and concentrated to $5 \mathrm{ml}$. This was chromatographed on diethylaminoethyl cellulose-52 (DEAE-52) using a stepwise $\mathrm{NaCl}$ gradient. The $0.15 \mathrm{M} \mathrm{NaCl}$ fraction contained purified secretory IgA.

Approximately $10 \mathrm{mg}$ of purified IgA were bound to a Reacti-Gel affinity column (Pierce Chemical Co., Rockford, IL) and $0.5 \mathrm{ml}$ of reconstituted goat anti-rat IgA serum (Organon Teknika, West Chester, PA) was applied to the column. After washing the column with 10 bed volumes of PBS, the affinity-purified antibody was eluted with 35 $\mathrm{ml}$ of $\mathrm{HCl}$ glycine, $\mathrm{pH} 2.0$. The affinity-purified antibody was dialyzed against PBS and stored at $4^{\circ} \mathrm{C}$. An aliquot of affinity-purified goat anti-rat IgA was conjugated to alkaline phosphatase (VII-S bovine, Sigma Chemical Co.) using glutaraldehyde (28).

Absorption of $P G$-PS polymers from blind loops. Intraluminal injections of PG-APS were performed in rats 4 wks after surgery. Three groups of five rats each were tested including $(a)$ sham-operated rats, (b) rats with SFBL treated with intravenous buffer $(0.1 \mathrm{M}$ potassium phosphate, $\mathrm{pH}$ 6.2), and (c) rats with SFBL treated with intravenous mutanolysin given $200 \mu \mathrm{g}$ three times per week beginning $24 \mathrm{~h}$ after the blind loop surgery. $4 \mathrm{wk}$ after surgery, rats were anesthetized, a laparotomy was performed, the blind loop or corresponding proximal jejunum was identified and 3,000 $\mu \mathrm{g}$ of rhamnose PG-APS was injected in a $1-\mathrm{ml}$ volume followed by $1 \mathrm{ml}$ of saline. The injection site was sealed with Krazy Glue (Jadow \& Sons, New York). The abdominal wall was closed and tail vein plasma samples were collected serially every $3 \mathrm{~h}$ for $\mathbf{4 2} \mathrm{h}$. Subsequently, plasma was assayed for PG-APS using ELISA (29). Mutanolysin was not given after intraloop injection. When rats were killed, the liver was removed, and $0.5-1.0 \mathrm{~g}$ liver was homogenized in $0.1 \mathrm{M}$ Tris $-0.1 \%$ Tween 20 , $\mathrm{pH} 8.0$ ( $1 \mathrm{~g}$ wet weight per $4 \mathrm{ml}$ of buffer) and assayed for PG-APS by ELISA.

Preparation of purified $P G$ and $P G-A P S$. The culture of bacteria and purification of PG-APS and PG from group A, type 3, strain D-58 streptococci was done by standard procedures which have been most recently described by Stimpson and Schwab (27).

Measurement of TNF $\alpha$ and AST. Blood was collected in EDTA $(1.5 \mathrm{mg} / \mathrm{ml})$ and aprotinin $(0.67 \mathrm{TIU} / \mathrm{ml})$ (Sigma Chemical Co.), centrifuged to collect plasma, and then stored at $-70^{\circ} \mathrm{C}$ until assayed. TNF $\alpha$ was measured using a mouse TNF $\alpha$ ELISA assay (Genzyme Corp., Cambridge, MA). The reagents of this ELISA cross-react with rat TNF $\alpha$. TNF $\alpha$ is measured in the range $50-1,000 \mathrm{pg} / \mathrm{ml}$ with a coefficient of variance of $8 \%$. Serial dilution of rat plasma gave parallel curves to mouse TNF $\alpha$ standard and recovery with addition of rat plasma to mouse standard was $75-95 \%$ for 10 experiments. Briefly, the assay was performed as follows. 96-well microtiter plates (Dynetech Laboratories, Alexandria, VA) were coated with hamster anti-mouse TNF $\alpha$ for $18 \mathrm{~h}$. A blocking step was performed for $1 \mathrm{~h}$ and then samples were added. After $18 \mathrm{~h}$ of incubation, goat anti-mouse TNF $\alpha$ was incubated for $4 \mathrm{~h}$. Donkey anti-goat IgG antibody conjugated with horseradish peroxidase was incubated for $1 \mathrm{~h}$. For the color reaction, a $5 \mathrm{mg} O$-phenylenediamine dihydrochloride tablet (Sigma Chemical Co.) was diluted in $12.5 \mathrm{ml}$ phosphate-citrate buffer and applied to the wells. Reactions were read at optical density 450 after 5 min using an ELISA reader. All incubations, except the first, were at $25^{\circ} \mathrm{C}$ and plates are washed five times between each incubation step.

The AST was measured in the clinical chemistry laboratory at University of North Carolina Hospitals by Seargen RA 1000 adaptation (Technicon, Tarrytown, NY) using P5P activation.

Kupffer cell isolation and in vitro culture. Kupffer cells were isolated from rat livers using a modification of the technique described by Knook and Sleyster (30). Rat livers were perfused in the intact animal by Krebs-Ringer-Heinsleit buffer for $5 \mathrm{~min}$ to remove blood. Then $0.025 \%$ collagenase (Boehringer-Mannheim Biochemicals, Indianapolis, IN) perfusion was performed in Gey's balanced salt solution (GBSS) until the liver softened ( $\sim 20 \mathrm{~min})$. Perfusions were performed using oxygenated solutions kept at $37^{\circ} \mathrm{C}$. Oxygen consumption was continuously monitored as a check for liver tissue viability.

After collagenase perfusion, the liver was raked with a steel comb in order to disperse cells, which were then centrifuged at $50 \mathrm{~g}$ for $2 \mathrm{~min}$. Hepatocytes formed a pellet; the supernatant, which consisted of nonparenchymal cells (Kupffer cells and endothelial cells), was saved. The hepatocyte pellet was washed three times more in GBSS; supernatants were pooled and made up to $15 \mathrm{ml}$ which were loaded into a model J2/21ME centrifugal elutriator (Beckman Instruments, Inc., Palo Alto, CA). The rotor (Beckman JE-6B) speed was $2,500 \mathrm{rpm}$ at $4^{\circ} \mathrm{C}$ and cells were elutriated at $10,18,21,36,42 \mathrm{ml} / \mathrm{min}$ with GBSS buffer. The purified Kupffer cell fraction was collected at $36 \mathrm{ml} / \mathrm{min}$. Approximately $20-40 \times 10^{6} \mathrm{Kupffer}$ cells were collected from a single liver. Cells were $98 \%$ viable using trypan blue and $75 \%$ stain with peroxidase on cytospin preparations. These cells readily phagocytosed fluorescent beads and released acid phosphatase and cathepsin.

Kupffer cells were cultured in 96-well microtiter plates (Falcon Plastics, Becton Dickinson \& Co., Lincoln Park, NJ) in RPMI 1640 with $10 \%$ low endotoxin fetal calf serum (FCS) at $37^{\circ} \mathrm{C}$ in $5 \% \mathrm{CO}_{2}$ at 2 
$\times 10^{6}$ cells per $\mathrm{ml}$. After $48 \mathrm{~h}$, culture media was changed and the following were added: culture medium alone; endotoxin (LPS from $E$. coli serotype 055:B5, Sigma Chemical Co.) $1 \mu \mathrm{g} / \mathrm{ml}$; or PG-APS $40 \mu \mathrm{g}$ rhamnose $/ \mathrm{ml}$. After $8 \mathrm{~h}$ of incubation, supernatants were frozen and stored at $-70^{\circ} \mathrm{C}$ for later measurement of TNF $\alpha$. In some experiments, $1,000 \mu \mathrm{g}$ of PG-APS was preincubated with $200 \mu \mathrm{g}$ of mutanolysin for $36 \mathrm{~h}$ at $37^{\circ} \mathrm{C} .<10 \mathrm{pg} / \mathrm{ml}$ of endotoxin were detected (as measured by Limulus amebocyte lysate assay) in RPMI culture media with FCS, PG-APS, and GBSS.

Statistical analysis. Comparison of luminal bacterial counts, body weights, plasma antibody levels, in vitro TNF $\alpha$ levels, AST, and histologic scores were performed by using the two-tailed Student's $t$-test. Incidences of culture-positive mesenteric lymph nodes and rates of spontaneous deaths were compared by using $\chi^{2}$.

\section{Results}

Effect of mutanolysin on hepatobiliary inflammation and clinical parameters. Plasma AST levels and histology scores were significantly lower in rats that received mutanolysin treatment beginning $24 \mathrm{~h}$ after creation of SFBL compared with rats with SFBL that received only buffer and were not significantly different from sham-operated and rats with SFBL (Table I). During the first experiment, which terminated $4 \mathrm{wk}$ after surgery, there were 0 of 8 spontaneous deaths in the mutanolysintreated group compared with $44 \%$ ( 4 of 9 ) of rats with SFBL that received buffer treatment, despite no difference in luminal concentration of anaerobic bacteria between mutanolysin- and buffer-treated groups (Table I). Heat-inactivated mutanolysin used for $\mathbf{4} \mathrm{wk}$ failed to prevent hepatobiliary injury, weight loss, and death (Table I). The second experiment, using continuous treatment ( $3 \mathrm{~d} / \mathrm{wk}$ ) with mutanolysin for $8 \mathrm{wk}$, confirmed that mutanolysin prevented hepatobiliary injury as manifested by plasma AST and hepatic histology. There were 0 of 6 spontaneous deaths in the mutanolysin-treated group compared with the simultaneously buffer-treated group which had 3 of 6 deaths, and treated rats gained weight rather than lost weight (Table I). The death rate of pooled data from rats treated with mutanolysin for 4 or 8 wk was 0 of 14 compared with 12 of 23 $(52 \%)$ in rats treated with buffer or heat-inactivated mutanolysin, $\chi^{2}=8.56, P<0.005$.

As reported previously (1-3) and confirmed in this study, rats with SEBL had luminal anaerobic bacterial counts of $10^{4-6}$ organisms per milliliter, developed no elevation of plasma AST, and had normal histology scores. Rats with SFBL treated with cyclosporin A (oral and i.m.), prednisone, methotrexate, and ursodeoxycholic acid for 4 wk had $10^{9-10}$ organisms per milliliter in the blind loop, gained weight less well, had elevated plasma AST levels, and elevated histology scores compared with sham-operated rats, rats with SEBL and mutanolysintreated rats with SFBL (Table I). Treatment with mutanolysin or any other drug had no effect on total bacterial concentrations. Histology scores of rats with SFBL treated with prednisone, methotrexate, and cyclosporin A (oral and i.m.) were slightly but not significantly lower than those of rats with SFBL treated with buffer or ursodeoxycholic acid. This suggests a mild degree of protection from these immunosuppressive

Table I. Effect of Mutanolysin, Ursodeoxycholic Acid, Methotrexate, Prednisone, and Cyclosporin A, on Prevention of SBBO-induced Hepatobiliary Injury in Rats

\begin{tabular}{|c|c|c|c|c|c|c|c|}
\hline Group* & $n$ & Died & $\begin{array}{l}\text { Days survived } \\
\text { (mean) }\end{array}$ & $\begin{array}{l}\text { Luminal } \\
\text { bacteria }\end{array}$ & $\begin{array}{l}\text { Weight } \\
\text { gain }\end{array}$ & AST & $\begin{array}{l}\text { Liver histology } \\
\text { score }\end{array}$ \\
\hline & & & & $\log _{10} C F U / m l$ & $g$ & U/liter & \\
\hline SHAM & 6 & 0 & $28 \pm 0$ & $3.9 \pm 1.1^{\prime}$ & $32 \pm 8^{\prime}$ & $75 \pm 12^{\|}$ & $1.6 \pm 0.9^{\prime \prime}$ \\
\hline SEBL & 6 & 0 & $28 \pm 0$ & $5.5 \pm 1.0^{\prime}$ & $25 \pm 12^{\prime \prime}$ & $82 \pm 18^{\prime \prime}$ & $2.4 \pm 1.1^{\prime \prime}$ \\
\hline SFBL-Buf ${ }^{\ddagger}$ & 9 & 4 & $24 \pm 5$ & $9.3 \pm 0.4$ & $-8 \pm 23$ & $240 \pm 142$ & $7.5 \pm 0.8$ \\
\hline SFBL-Mut ${ }^{\ddagger}$ & 8 & 0 & $28 \pm 0$ & $9.0 \pm 0.5$ & $-1 \pm 16$ & $111 \pm 32^{\| 1}$ & $2.9 \pm 1.7^{1}$ \\
\hline SFBL-Mut (heated) ${ }^{\ddagger}$ & 8 & 5 & $22 \pm 5$ & $9.4 \pm 0.8$ & $-27 \pm 16$ & $183 \pm 67$ & $7.7 \pm 1.2$ \\
\hline SFBL-Buf ${ }^{\S}$ & 6 & 3 & $33 \pm 15$ & $9.1 \pm 0.4$ & $-21 \pm 26$ & $228 \pm 146$ & $8.2 \pm 1.9$ \\
\hline SFBL-Mut ${ }^{\S}$ & 6 & 0 & $56 \pm 0^{* *}$ & $9.5 \pm 0.9$ & $3 \pm 21$ & $101 \pm 37^{\prime \prime}$ & $2.2 \pm 2.7^{* *}$ \\
\hline SFBL-URSO & 7 & 0 & $38 \pm 11$ & $9.6 \pm 0.7$ & $-11 \pm 21$ & $235 \pm 134$ & $8.3 \pm 1.1$ \\
\hline SFBL-MTX ${ }^{\ddagger}$ & 5 & 1 & $28 \pm 9$ & $9.5 \pm 0.6$ & $-11 \pm 26$ & $279 \pm 150$ & $6.2 \pm 1.1^{\| 1}$ \\
\hline SFBL-PRED ${ }^{\ddagger}$ & 5 & 1 & $22 \pm 9$ & $9.2 \pm 0.6$ & $-35 \pm 17^{\| \prime}$ & $277 \pm 142$ & $6.5 \pm 2.4$ \\
\hline \multicolumn{8}{|l|}{ SFBL-CYCLO ${ }^{\ddagger}$} \\
\hline Enteral & 10 & 3 & $27 \pm 7$ & $9.5 \pm 0.7$ & $-28 \pm 24$ & $390 \pm 147$ & $6.9 \pm 1.8$ \\
\hline Intramuscular & 8 & 6 & $20 \pm 3$ & $9.8 \pm 0.4$ & $-28 \pm 9$ & $259 \pm 83$ & $6.6 \pm 1.1$ \\
\hline
\end{tabular}

All values are mean \pm SD. Abbreviations: SHAM, rats with sham operation 4 wk before sacrifice; SEBL, rats with SEBL (surgical control) 4 wk before sacrifice; SFBL-Buf, rats with SFBL treated with i.v. $0.1 \mathrm{M}$ potassium phosphate buffer, pH 6.2, three times weekly; SFBL-Mut, rats with SFBL treated with i.v. mutanolysin $200 \mu \mathrm{g}$ per rat, three times weekly; SFBL-Mut (heated), rats with SFBL treated with i.v. mutanolysin $200 \mu \mathrm{g}$ per rat three times weekly for $4 \mathrm{wk}$; mutanolysin was inactivated by boiling $15 \mathrm{~min}$; URSO, ursodeoxycholic acid therapy $15 \mu \mathrm{g} / \mathrm{kg}$ per $\mathrm{d}$ for $4 \mathrm{wk}$ by gavage feeding; MTX, methotrexate $0.015 \mathrm{mg}$ three times weekly for $4 \mathrm{wk}$ in drinking water; PRED, prednisone therapy $2 \mathrm{mg} / \mathrm{kg}$ per $\mathrm{d}$ for $4 \mathrm{wk}$ in drinking water; CYCLO, cyclosporin A treatment $15 \mathrm{mg} / \mathrm{kg}$ per d either in drinking water or intramuscularly $20 \mathrm{mg} / \mathrm{kg}$ per d for $4 \mathrm{wk}$. ${ }^{*}$ Treatment started $24 \mathrm{~h}$ after surgery and continued until rats were killed. ${ }^{\ddagger}$ Treatment for $4 \mathrm{wk}$ three times per week. ${ }^{\$}$ Treatment for $8 \mathrm{wk}$ three times per week. Compared to SFBL-Buf treated for $4 \mathrm{wk}, \quad " P<0.05$; $\quad P<0.001$; Compared to SFBL-Buf treated for 8 wk, ** $P<0.005$. 
Table II. Effect of Mutanolysin Therapy Which Was Started after Biochemical Evidence of SBBO-induced Hepatobiliary Injury

\begin{tabular}{|c|c|c|c|}
\hline & SFBL-Buffer* & SFBL-Mut ${ }^{\ddagger}$ & SFBL-Mut ${ }^{\$}$ \\
\hline Number per group & 11 & 11 & 4 \\
\hline Weight gain $(g)^{\|}$ & $-13 \pm 25$ & $19 \pm 11^{\ddagger \pm}$ & $-24 \pm 8$ \\
\hline \multicolumn{4}{|l|}{ AST $(u / \text { liter })^{\pi}$} \\
\hline Pre-op & $75 \pm 13$ & $80 \pm 25$ & $73 \pm 15$ \\
\hline Pre-Rx & $108 \pm 52$ & $142 \pm 80$ & $219 \pm 40^{* *}$ \\
\hline End expt & $247 \pm 142$ & $103 \pm 24^{* *}$ & $172 \pm 102^{\$ \$}$ \\
\hline \multicolumn{4}{|l|}{ RX started (days } \\
\hline after surgery) & $17 \pm 1$ & $17 \pm 2$ & $45 \pm 10^{\ddagger \pm||||}$ \\
\hline Duration of $\mathbf{R x}$ (days) & $16 \pm 9$ & $45 \pm 11^{\ddagger \ddagger}$ & $33 \pm 21^{* *}$ \\
\hline Death (days after surgery) & $33 \pm 9$ & $62 \pm 12^{\ddagger \ddagger}$ & $76 \pm 15^{\ddagger \ddagger}$ \\
\hline Deaths/total number (\%) & $5 / 11(45 \%)$ & $1 / 11^{* *}(9 \%)$ & $2 / 4(50 \%)$ \\
\hline Histology score & $7.1 \pm 2.4$ & $2.6 \pm 2.0^{\ddagger \ddagger}$ & $6.5 \pm 1.7^{1111}$ \\
\hline
\end{tabular}

* Rats with SFBL treated with intravenous $0.1 \mathrm{M}$ potassium phosphate buffer, three times weekly. ${ }^{\ddagger}$ Rats with SFBL treated with intravenous mutanolysin, $200 \mu \mathrm{g}$ per rat three times weekly, starting 16-21 d after surgery. ${ }^{\S}$ Rats with SFBL treated with intravenous mutanolysin, $200 \mu \mathrm{g}$ per rat three times weekly, starting 33-53 d after surgery. "Weight gain from time of surgery. 'Plasma AST before surgery (pre-op), before starting therapy (pre-Rx), and at the termination of the experiment (end expt). Compared to SFBL-Buffer, ${ }^{* *} P$ $<0.05$; $^{\ddagger} P<0.001$; compared to SFBL-Mut, ${ }^{\$} P<0.05$; $^{\text {IIII }} P<0.001$.

drugs although death rates and plasma AST were no different than in rats treated with buffer. Prednisone-treated rats actually lost more weight than buffer-treated rats.

The blind loop intestinal mucosa was examined histologically by two blinded observers and no difference was found between mutanolysin-treated groups and rats with SFBL that received buffer or heat-treated mutanolysin. Histology consisted of thickened mucosa, muscular, and serosal layers. There were no mucosal ulcerations in any samples. Both groups dem- onstrated a marked mononuclear cell infiltration in the mucosal layer.

To determine where mutanolysin could treat as well as prevent hepatobiliary injury, i.v. mutanolysin was started 16-21 d after SFBL surgery when plasma AST was elevated (142 \pm 80 $\mathrm{U} /$ liter) compared to presurgical values $(80 \pm 25 \mathrm{U} /$ liter $), P$ $<0.025$. Delayed treatment led to final AST and histology scores which were significantly lower than those of rats with SFBL treated with buffer (Table II). Rats were electively killed 42-78 d after surgery, i.e., 25-61 d after starting mutanolysin treatment, yet hepatic histology was nearly normal. There was one death in the group that received mutanolysin starting 16$21 \mathrm{~d}$ after SFBL surgery and weight gain was $18 \pm 11 \mathrm{~g}$, both significantly better than in rats with SFBL treated with buffer. 9 of 11 buffer-treated rats demonstrated an increase in AST by $>50 \mathrm{U} /$ liter from pretreatment values and no rat had declining values. This is significantly different than mutanolysintreated rats of which 7 of 11 had declining AST values and no rat had an increase in AST $>50 \mathrm{U} /$ liter, $P<0.001$ (Fig. 1). When i.v. mutanolysin treatment was delayed until plasma AST values were quite elevated $(219 \pm 40 \mathrm{U} /$ liter at $33-53 \mathrm{~d}$ after SFBL surgery), there was less protection, in $50 \%$ ( 2 of 4 ) of the treated rats died. The two survivors were treated with mutanolysin for 31 and $62 \mathrm{~d}$ before being electively killed. Plasma AST were lower than they had been when treatment was started and histology scores were 5 and 6 in the two surviving rats compared to historical scores of 8-11 in rats with SFBL for this long duration $(1,2)$. In the other two rats in this group, AST did not improve and death occurred spontaneously in one and by accidental ether overdose during blood collection in another.

Bacteriology results. Cultured liver, spleen, cardiac blood, and peritoneal swabs were negative for bacterial growth in all rats. Mesenteric lymph nodes were culture-positive in $16 \%$ ( 1 of 6) of rats with SEBL but were positive in $80 \%$ ( 8 of 10$), 88 \%$ ( 7 of 8 ), $83 \%$ ( 15 of 18 ), $100 \%$ ( 5 of 5 ), $80 \%$ ( 4 of 5 ), $86 \%$ ( 6 of 7) of rats treated with buffer, mutanolysin, cyclosporin A (oral

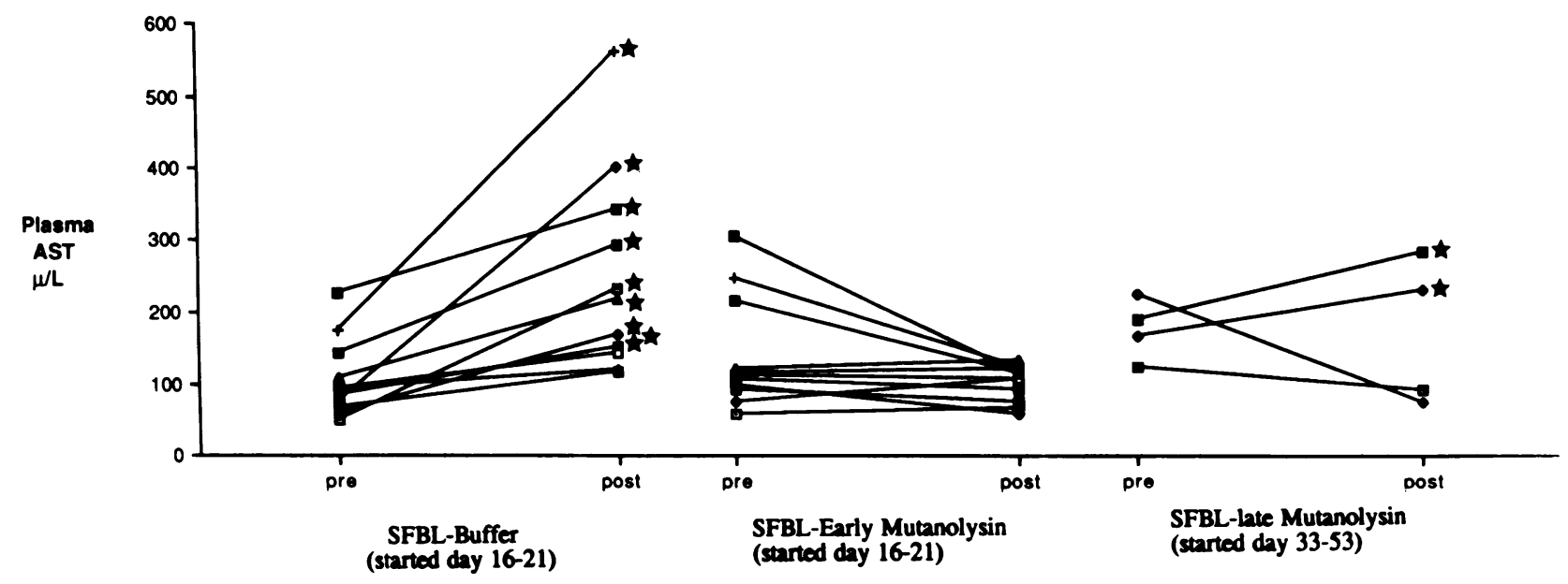

Figure 1. Change in plasma AST with mutanolysin therapy of rats with SBBO. Individual plasma AST (units per liter) from rats were tested before treatment was started ( pre). Treatment consisted of IV buffer ( started 16-21 d after surgery, $n=11$ ), early mutanolysin treatment ( started 16-21 d after surgery, $n=11$ ) and late mutanolysin treatment (started 33-53 d after surgery, $n=4$ ). AST levels were tested at the end of the experiment (post). Mutanolysin was given i.v. $200 \mu \mathrm{g}$ three times per week. ${ }^{*}$ Posttreatment AST values which increased $>50 \mathrm{U} /$ liter compared to pretreatment levels. 9 of 11 rats demonstrated an increase in AST of $>50 \mathrm{U} /$ liter in buffer-treated rats compared to 0 of 11 rats treated with mutanolysin beginning days $16-21, \chi^{2}=12.03, P<0.001$. 

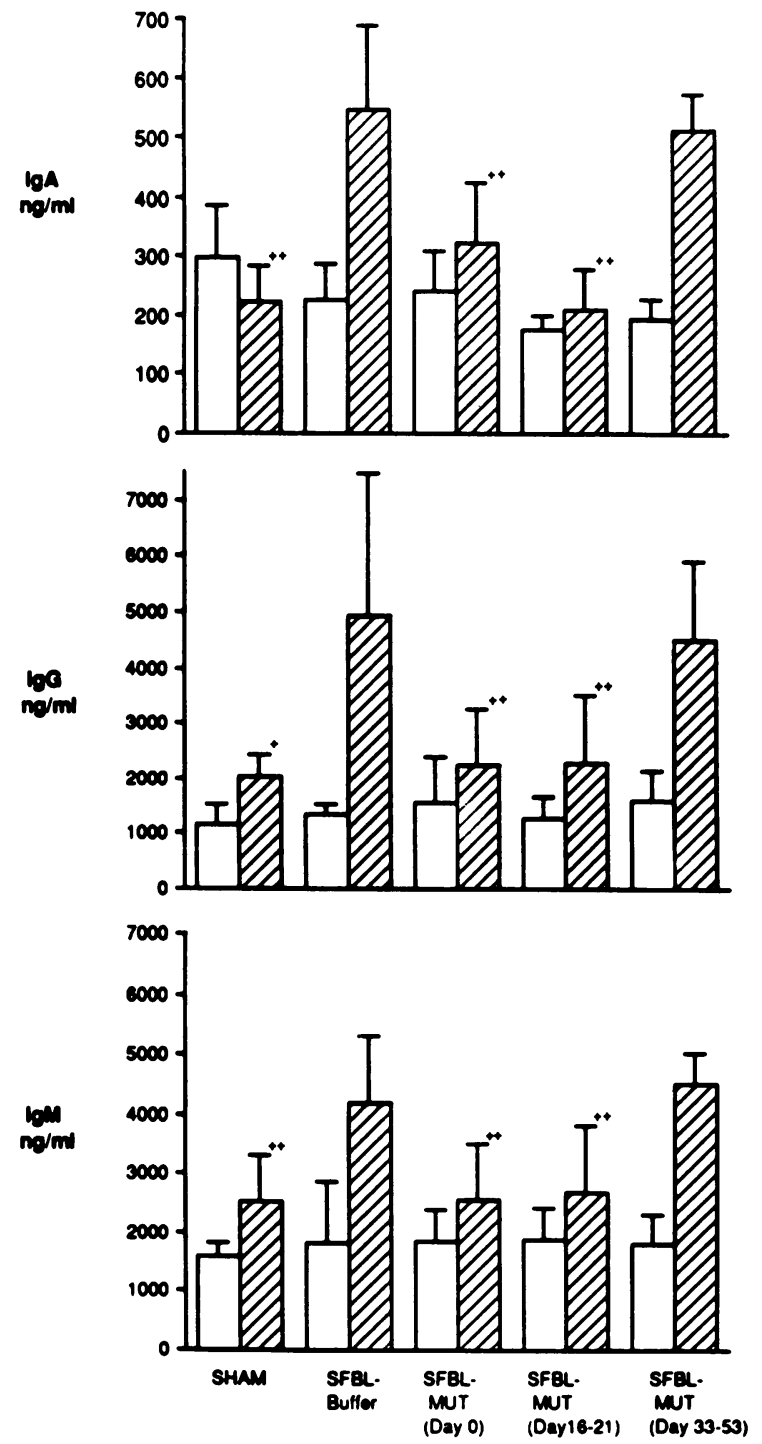

Figure 2. Plasma anti-PG antibody levels after mutanolysin treatment. Plasma anti-PG IgA, IgG, and IgM levels drawn at the time of surgery (open boxes) and at the end of the experiment (hatched lines). Antibodies were measured by ELISA. Values represent mean \pm SD. $S H A M$, sham-operated rats, $n=6 . S F B L$, rats with SFBL, treated with buffer beginning the day of surgery, $n=10$. SFBL-Mut (day 0), rats with SFBL treated with mutanolysin beginning the day of surgery, $n=12$. SFBL-Mut (days 16-21), rats with SFBL treated with mutanolysin beginning 16-21 d after surgery, $n=11$. SFBL-Mut (days 33-53), rats with SFBL treated with mutanolysin beginning 33-53 d after surgery, $n=4 .{ }^{+} P<0.05 ;{ }^{++} P<0.01$ for levels drawn at the end of the experiment, compared to SFBL-buffer-treated rats.

and i.m.), prednisone, methotrexate, and ursodeoxycholic acid, respectively $\left(\chi^{2}=8.96,14.70,10.21,11.37,7.95,9.29 ; P\right.$ $<0.005$ for all relative to rats with SEBL), indicating a significantly greater amount of bacterial translocation to mesenteric lymph nodes in rats with SFBL regardless of treatment.

Cultures of blind loop contents in rats with SFBL showed $10^{8-10}$ organisms per milliliter regardless of treatment (Table I). Subcultures of blind loop contents revealed the presence of Bacteroides sp. in all rats tested (6 of 6) that received mutanolysin treatment. When $10 \mu \mathrm{g}(10 \mu \mathrm{l})$ mutanolysin were added directly to dilutions of blind loop contents, no difference in colony-forming units was detected at the dilutions tested, $\left(10^{-7}\right.$ to $10^{-10}$ ) in six rats.

Antibody in plasma specific for $P G$. We have used plasma anti-PG antibodies as an indirect indicator of luminal PG-PS absorption (3). Plasma anti-PG IgA, IgG, and IgM antibodies were significantly increased 4 wk after surgery in rats with SFBL treated with buffer, or mutanolysin starting 33-53 d after surgery; no such increase in anti-PG antibodies occurred in rats with SFBL treated with mutanolysin beginning 0 or 16-21 d after surgery (Fig. 2). Sham-operated rats showed small but significant elevations in anti-PG-IgG and anti-PG-IgM antibodies when preoperative levels were compared to levels obtained when rats were killed, indicating continued exposure to luminal PG from normal bacterial flora and/or maturation of the immune system. Rats treated with mutanolysin from day 0 and from days 16 to 21 had almost exactly the same anti-PG antibody levels as sham-operated rats. Therefore, early treatment with mutanolysin (before $21 \mathrm{~d}$ after surgery) reduced the large elevations of anti-PG antibodies which occurred in rats with SFBL which were treated with buffer, but delayed treatment with mutanolysin beginning 33-53 d after surgery had no effect on anti-PG antibodies or hepatobiliary inflammation.

Absorption of PG-APS after intraluminal injection. As a more direct measure of systemic absorption of PG-PS from the SFBL, PG-APS was injected intraluminally. Because the APS moiety is antigenically distinct from cell wall antigens of normal rat microbial flora, plasma levels of PG-APS provide a sensitive index of absorption of exogenous luminal PG-PS. After a single intraluminal injection, PG-APS was measured in 12 serial plasma samples taken over the next $42 \mathrm{~h}$ from shamoperated rats, rats with SFBL treated with mutanolysin, or rats with SFBL treated with buffer. The plasma levels in shamoperated rats peaked at $6 \mathrm{~h}(18 \pm 7 \mathrm{ng} / \mathrm{ml})$ and then rapidly declined, but were elevated for 3-30 h in rats with SFBL with

Table III. Systemic Absorption of 3,000 $\mu \mathrm{g}$ of PG-APS after Injection into the Blind Loop or Corresponding Area of Jejunum of Sham-operated Rats 4 wk after Surgery

\begin{tabular}{lcc}
\hline \multicolumn{1}{c}{ Expt group* } & Area under curve & Total liver PG-APS \\
\hline & square units & $n g / g$ liver \\
SFBL-Buffer & $30 \pm 4$ & $153 \pm 70$ \\
SFBL-Mut & $42 \pm 19$ & $116 \pm 37$ \\
SHAM & $4 \pm 3^{\prime \prime}$ & $20 \pm 12^{1}$ \\
\hline
\end{tabular}

Abbreviations: SFBL-Buf, rats with SFBL treated with i.v. $0.1 \mathrm{M}$ potassium phosphate buffer three times weekly; SFBL-Mut, rats with SFBL treated with i.v. mutanolysin $200 \mu \mathrm{g}$ per rat three times weekly, starting within $24 \mathrm{~h}$ of surgery and stopping $24 \mathrm{~h}$ before the injection of PG-APS into the blind loop. SHAM, sham-operated rat receiving no therapy. * Each experimental group had five rats and values are mean \pm SD. ${ }^{\ddagger}$ Area under the curve of a plot with plasma PG-APS $(\mathrm{ng} / \mathrm{ml})$ on the vertical axis and time (hours) on the horizontal axis. The values are arbitrary square units $\left(\mathrm{ng} / \mathrm{ml} \times\right.$ time in hours). ${ }^{8}$ Rats were killed $42 \mathrm{~h}$ after injection of the blind loop or corresponding jejunum and livers were removed. Liver tissue was homogenized and assayed for PG-APS content using ELISA. Compared to SFBL-Mut, " $P<0.05 ;{ }^{1} P<0.025$. 
or without mutanolysin treatment. Peak levels for rats with SFBL treated with buffer were $29 \pm 11 \mathrm{ng} / \mathrm{ml}$ at $15 \mathrm{~h}$ and $33 \pm 14$ $\mathrm{ng} / \mathrm{ml}$ ( mean $\pm \mathrm{sd}$ ) at $15 \mathrm{~h}$ for rats with SFBL treated with mutanolysin. Both of these values were significantly greater than corresponding levels from sham-operated rats, $P<0.05$. Significantly elevated levels were also found at 3 and $30 \mathrm{~h}$ for rats with SFBL with and without mutanolysin treatment compared with sham-operated rats, $P<0.05$; plasma PG-APS levels were consistently higher in both groups with SFBL compared with sham-operated rats. The cumulative results (as measured by calculating the area under a curve for a graph using PG-APS nanograms per milliliter on the vertical axis and time in hours on the horizontal axis), from rats with SFBL with buffer treatment and those with SFBL that were treated with mutanolysin, showed significantly more absorption of PG-APS into plasma compared to sham-operated rats (Table III). Thus, mutanolysin treatment did not alter absorption of PG-APS into the plasma (Table III). Similarly, hepatic concentrations of PGAPS were significantly greater in rats with SFBL with or without mutanolysin treatment compared to low levels found in livers of sham-operated rats which received the same intraluminal dose of PG-APS (Table III). Liver homogenates from rats which have never been injected with PG-APS contain $<2$ $\mathrm{ng} / \mathrm{g}$ liver (3) which is $\mathbf{1 0}$-fold lower than values in sham-operated rats injected with PG-APS. These data confirm that PGPS absorption is increased from an SFBL relative to normal intestine (3) and show that prolonged mutanolysin treatment did not alter mucosal permeability to these macromolecules. It should be noted that mutanolysin therapy was stopped $1 \mathrm{~d}$ before instillation of PG-APS into the lumen.

In vivo and in vitro $T N F \alpha$ measurements. Plasma samples were drawn every 3-7 d after creation of SFBL in rats treated with buffer or mutanolysin to serially measure circulating TNF $\alpha$ ( Table IV). Baseline values before surgery (day 0 ) for six rats receiving buffer and six rats receiving mutanolysin was $61 \pm 12 \mathrm{pg} / \mathrm{ml}$ (mean $\pm \mathrm{SD}$ ). A significantly elevated plasma level was considered to be $>2$ SD above the mean, $(>85 \mathrm{pg}$ / $\mathrm{ml})$. The TNF $\alpha$ ELISA detection limits are $50 \mathrm{pg} / \mathrm{ml}$ and any samples below detection were arbitrarily assigned a value of 50 $\mathrm{pg} / \mathrm{ml}$. In the six buffer-treated rats with SFBL, during days 3 , 6 , and 9 after surgery, only two plasma samples were consid-

Table IV. Plasma TNF $\alpha$ Levels in Rats with SBBO with and without Mutanolysin Treatment

\begin{tabular}{lcl}
\hline & SFBL-Buffer & \multicolumn{1}{c}{ SFBL-Mutanolysin } \\
\hline & \multicolumn{2}{c}{$p g / m l^{*}$} \\
Day 0 & $66 \pm 14$ & $56 \pm 11$ \\
Day 3 & $57 \pm 8$ & $56 \pm 8$ \\
Day 6 & $62 \pm 15$ & $55 \pm 8$ \\
Day 9 & $80 \pm 22$ & $61 \pm 10$ \\
Day 15 & $84 \pm 37$ & $60 \pm 8$ \\
Day 18 & $114 \pm 30^{\ddagger}$ & $62 \pm 14$ \\
Day 21 & $101 \pm 44^{\ddagger}$ & $56 \pm 7$ \\
Day 28 & $120 \pm 17^{\S}$ & $61 \pm 13$ \\
& & \\
\hline
\end{tabular}

* All values are mean \pm SD for each group containing six rats. For rats with SBBO treated with buffer compared to those treated with mutanolysin, ${ }^{\ddagger} P<0.05,{ }^{8} P<0.001$.
Table V. TNF $\alpha$ Release from Cultured Kupffer Cells*

\begin{tabular}{lc}
\hline & TNF \\
\hline $\mathrm{KC}+$ media alone & $p g / m l^{*}$ \\
$\mathrm{KC}+$ LPS $(1 \mu \mathrm{g} / \mathrm{ml})$ & $<50$ \\
$\mathrm{KC}+$ PG-APS $(40 \mu \mathrm{g} / \mathrm{ml})$ & $311 \pm 71$ \\
$\mathrm{KC}+$ mutanolysin-digested PG-APS & $486 \pm 71$ \\
& $145 \pm 44$ \\
\hline
\end{tabular}

${ }^{*}$ Kupffer cells $(\mathrm{KC})$ were cultured at $2 \times 10^{6}$ cells/ml for $48 \mathrm{~h}$ before addition of LPS, PG-APS, or mutanolysin-digested PG-APS. ${ }^{\ddagger}$ Data represent results mean \pm SD from four different experiments. ${ }^{\S} 1,000$ $\mu \mathrm{g}$ of PG-APS was preincubated with $200 \mu \mathrm{g}$ of mutanolysin at $37^{\circ} \mathrm{C}$ for $36 \mathrm{~h}$ and $40 \mu \mathrm{g} / \mathrm{ml} \mathrm{PG-APS}$ was added to Kupffer cell cultures.

ered elevated out of 18 samples but on days $15,18,21$, and 28 , 16 samples out of $24(66 \%)$ were $>85 \mathrm{pg} / \mathrm{ml}$. In rats with SFBL that were treated with mutanolysin, no plasma samples were elevated in the first $9 \mathrm{~d}$ after surgery and only 2 of 24 samples (8\%) were elevated from days $15,18,21$, and 28 after surgery. The difference in elevated plasma TNF $\alpha$ levels between mutanolysin-treated rats with SFBL and buffer-treated rats was significant ( $\chi^{2}=16.60, P<0.001$ ). Table IV demonstrates that rats with SFBL treated with mutanolysin had plasma TNF $\alpha$ levels which remained at low background levels for the duration of the experiment, in contrast to those rats treated with buffer which increased with time. TNF $\alpha$ levels of buffer-treated rats were statistically greater than mutanolysintreated rats at days 18,21 , and 28 .

Purified Kupffer cells were cultured for $48 \mathrm{~h}$ and then incubated with LPS, PG-APS, or mutanolysin-digested PG-APS. Supernatants from these cultures were assayed for TNF $\alpha$ ( Table V). LPS $(1 \mu \mathrm{g} / \mathrm{ml})$ and PG-APS $(40 \mu \mathrm{g} / \mathrm{ml})$ both caused large releases of TNF $\alpha$ but when PG-APS was degraded by mutanolysin, TNF $\alpha$ production was decreased by $75 \%$ and was not significantly elevated above levels from unstimulated Kupffer cells (Table V).

\section{Discussion}

Demonstration that the muralytic enzyme mutanolysin prevented experimental hepatobiliary injury in rats with SBBO supports the hypothesis that systemic absorption of endogenous PG-PS from luminal bacteria causes this lesion. Because there was no reduction of total intestinal anaerobic bacterial counts, no elimination of Bacteroides sp. from the lumen of the SFBL, and no prevention of bacterial translocation to mesenteric lymph nodes, we conclude that mutanolysin had no apparent antibiotic properties. We directly tested this observation by adding mutanolysin to dilutions of enteric organisms from the blind loop and found that the number of colony-forming units on culture plates was not significantly different with or without mutanolysin. The only known biologic activity of mutanolysin is to split the $\beta$ 1-4 linkage of $N$-acetyl muramic acid- $N$-acetyl glucosamine in PG, which renders the PG-PS polymer unable to initiate or sustain chronic inflammation $(20,21)$. Previous studies showed that the chronicity of systemic inflammation caused by i.p. PG-APS injection was affected by the molecular 
weight of PG-PS, in that smaller polymers $\left(<5 \times 10^{6} \mathrm{~mol} \mathrm{wt}\right)$ caused only acute inflammation while larger PG-PS fragments caused chronic, spontaneous relapsing inflammation (31). High molecular weight PG-APS remained in inflamed tissues for at least $3 \mathrm{mo}(16,29)$ and caused chronic relapsing inflammation. PG-PS from certain bacteria such as Peptostreptococcus causes only transient inflammation, whereas PG-PS from group A streptococci and Eubacteria cause chronic granulomatous inflammation $(14,15)$. These observations demonstrate that chronicity of inflammation induced by PG-PS correlates with persistence of cell wall polymers in tissues, i.e., poorly biodegradable, larger polymers induce chronic inflammation, but easily degradable polymers cause only acute, transient inflammation (11,17-19). Thus, mutanolysin could protect tissues from injury by degrading PG-PS before this polymer could activate immunocytes as demonstrated by the decrease in TNF $\alpha$ production by Kupffer cells exposed to PGPS digestion with mutanolysin. Additionally, mutanolysin can reduce injury even after inflammation has been established, as has been demonstrated by in vivo studies with this enzyme in models of exogenously administered PG-PS. A single i.v. injection of mutanolysin was able to prevent chronic arthritis and granulomatous hepatitis when given $3 \mathrm{~d}$ after i.p. PG-APS and greatly reduced severity of disease even when given $14 \mathrm{~d}$ after PG-APS (21). In recent preliminary studies, i.v. mutanolysin prevented chronic enterocolitis when given at the time of subserosal PG-APS injection and diminished injury even when given up to $7 \mathrm{~d}$ after onset of the chronic relapsing phase of inflammation, $21 \mathrm{~d}$ after PG-APS injection (22).

This study confirms the association of SBBO and hepatobiliary injury (1-4) and explores mechanisms of tissue inflammation. Ursodeoxycholic acid did not prevent injury, making toxicity by bacterially altered bile salts unlikely. Similar doses of ursodeoxycholic acid effectively treated liver disease caused by bile duct ligation in rats (32) although a significant beneficial effect on histology was not obvious (33). The possibility that the immune response plays a major role in the pathogenesis of hepatic injury was studied by examining the effect of methotrexate, prednisone, and cyclosporin A. None of these immunosuppressive drugs prevented hepatobiliary injury. Methotrexate, cyclosporin A, and prednisone slightly decreased the histology score but other parameters, such as increased plasma AST and death rate, were not altered. Cyclosporin A has been shown to prevent development of hepatic granulomas in rats injected i.p. with PG-APS (25). However, those studies investigated inflammation induced by a large single i.p. injection of bacterial polymers derived from an organism not typically found in rats. In rats with SBBO, the hepatobiliary injury may differ from injury induced by a single i.p. bolus of PG-APS because of sustained exposure to endogenous bacteria which contain heterogeneous PG polymers. This continuous exposure probably results in a lower daily dose of cell wall polymers, although the cumulative amount of PG-PS absorbed may be large. No granulomas occur in SBBO-induced hepatobiliary injury and the injury requires a slightly longer time to develop than the injury that follows i.p. injection of PG-APS. Another reason for differences between i.p. PG-APS and SBBO-associated liver disease is the source of PG-PS. Most enteric bacterial PG-PS induces only transient inflammation, although some species of normal flora bacteria produce poorly biodegradable PG-PS capable of inducing chronic granulomatous inflammation (13,
14). Rats with experimental SBBO are exposed to a large number of different PG-PS polymers derived from the diverse enteric bacterial species that proliferate within the blind loop (5).

Mutanolysin therapy could prevent hepatobiliary injury in rats with SBBO by several mechanisms, including decreasing absorption of PG-PS, splitting PG-PS after mucosal absorption but before stimulation of immune cells, or enhancing degradation after tissue accumulation occurs. To test the effect of mutanolysin therapy on intestinal absorption and immune response, plasma anti-PG IgA, IgG, and IgM antibodies were assayed before surgery and when rats were killed. The levels of these antibodies increased in rats with SBBO receiving buffer treatment but did not increase in rats with SFBL treated with mutanolysin starting immediately after blind loop surgery or 16-21 d after surgery. However, mutanolysin treatment delayed until 33-53 d after SFBL surgery did not prevent elevation of anti-PG antibodies. The presence of a low baseline of anti-PG antibodies in rats and humans has been documented in the past (9) and indirectly reflects mucosal absorption of antigenic PG to which normal animals are continually exposed. The absence of increased anti-PG antibodies after early initiation of mutanolysin therapy may indicate a lack of absorption from the intestine or that degradation of PG occurs before stimulation of the humoral immune response. Elevated anti-PG antibodies are probably of no pathogenic significance in that they did not correlate with hepatic injury (1). Anti-PG antibody levels also did not correlate with the degree of arthritis after i.p. injection of PG-PS (34). They represent one measure of absorption of PG-PS in that they were not elevated in Lewis rats treated with metronidazole, a treatment which diminishes PG-APS absorption after injection into the blind loop presumably by decreasing mucosal injury (2). Buffalo rats, which develop no hepatobiliary injury associated with SBBO although they also develop mucosal injury $(1,4)$, displayed elevated anti-PG IgG, IgA, and IgM (data not published). Buffalo rats develop similar disaccharidase deficiency, similar increases in anaerobic bacterial numbers as Lewis rats (1) and absorbed PG-APS after intraloop injection to a similar degree as Lewis rats. This data indicate that despite similar absorption of PGPS across injured mucosa of the SFBL, Buffalo rats are resistant to the chronic hepatobiliary inflammation which occurs in Lewis rats. This is consistent with previous data comparing tissue levels of PG-APS after i.p. injections. On days 3 and 30 after i.p. injection, high responding Sprague-Dawley rats and Buffalo rats had similar joint and hepatic concentrations of PG-APS but the high responding rats developed chronic granulomatous inflammation whereas Buffalo rats had normal histology (35).

To directly test the effect of mutanolysin on intestinal absorption of PG-PS, uptake of PG-APS from blind loops was compared among rats with sham-operation or with SFBL treated with mutanolysin or phosphate buffer for 4 wk after surgery. Serial plasma levels of PG-APS, during $42 \mathrm{~h}$ after injection of PG-APS into the blind loop, and liver content when rats were killed were no different between the mutanolysinand buffer-treated groups and were significantly higher than values obtained in sham-operated rats. Systemic mutanolysin therapy also had no apparent beneficial effect on intestinal inflammation within the SFBL. Thus chronic parenteral mutanolysin treatment does not prevent absorption of PG-PS from the intestinal lumen. This would imply that degradation of 
PG-PS by mutanolysin occurs before stimulation of the humoral immune response and possibly before phagocytosis and activation of Kupffer cells. The latter suggestion is supported by diminished TNF $\alpha$ production by PG-APS digestion in vitro using mutanolysin. We previously showed that PGAPS extracted from liver tissue 1, 3, and $15 \mathrm{~d}$ after i.p. injection was significantly degraded in rats treated in vivo with mutanolysin (19).

Mutanolysin therapy diminished in vivo and in vitro TNF $\alpha$ production, suggesting that TNF $\alpha$ may have an important role in the pathogenesis of hepatobiliary inflammation induced by SBBO. Mutanolysin treatment almost totally prevented increased plasma TNF $\alpha$ levels which developed by $18 \mathrm{~d}$ in untreated rats with SBBO. We have previously shown that administration of palmitate, which blocks phagocytosis by Kupffer cells, and pentoxifylline, which blocks TNF $\alpha$ secretion by Kupffer cells, both prevented hepatic injury in rats with SBBO (36). Therefore, mutanolysin could function in part by degrading absorbed PG-PS before Kupffer cell activation occurs thereby preventing release of cytokines, prostaglandins, leukotrienes and other inflammatory mediators involved in hepatobiliary injury. For example, we have recently shown that IL-1 and the kallikrein-kinin system have a role in the pathogenesis of chronic inflammation induced by PG-APS (37-39).

These experiments directly support previously reported indirect evidence that luminal PG-PS from jejunal SFBL causes hepatobiliary inflammation. We have demonstrated that: antiPG antibodies are increased in rats with SBBO (3); increased absorption of luminal PG-APS occurs in rats with SBBO (3); hepatobiliary injury is prevented by metronidazole (2); there is enterohepatic circulation of PG-APS (40); and inbred rat strains have similar susceptibilities to SBBO-induced hepatobiliary injury as that which occurs after i.p. injection of PG-APS which induces chronic liver granulomas (10) and arthritis (11). Based on these results and the present evidence that mutanolysin prevents and treats hepatic injury associated with SBBO, we conclude that PG-PS from an overgrowth of endogenous anaerobic enteric bacteria can cause chronic hepatobiliary inflammation in genetically susceptible rats. Previous reports document the inflammatory potential of intestinal bacteria and their cell wall polymers. Stimpson et al. (14) showed that purified PG-PS from normal intestinal flora was arthropathogenic in rats and Severijnen et al. (15) showed that purified PG-PS from several strains of Eubacterium produced chronic arthritis in rats after systemic injection. Subserosal injections of purified PG-PS from group D streptococci cause chronic enterocolitis (13). Normal flora bacteria, bacterial products, and luminal PG-APS can potentiate nonspecific enterocolitis after acute intestinal injury $(41,42)$ and Lewis rats, but not Fischer F334, with intestinal injury induced by indomethacin develop hepatomegaly and liver inflammation (43). Experiments presented here show that mutanolysin, whose only known function is to degrade PG-PS, is effective in preventing and treating hepatobiliary injury associated with experimental SBBO. Further work to demonstrate a role for endogenous PG-PS in causing and / or perpetuating chronic inflammatory diseases such as chronic inflammatory bowel disease and its extraintestinal manifestations, especially hepatobiliary inflammation and arthritis, in humans is required. Potential treatment of such diseases with mutanolysin or a derivative of this muralytic enzyme is suggested.

\section{Acknowledgments}

The work was supported in part by a Career Development Award from the Crohn's and Colitis Foundation of America (Dr. Lichtman) and by U. S. Public Health Service grants from the National Institutes of Health (DK-40249 [Dr. Sartor], AR-39480 [Dr. Schwab]) and from the Center for Gastrointestinal Biology and Disease (DK-34987).

\section{References}

1. Lichtman, S. N., R. B. Sartor, J. Keku, and J. H. Schwab. 1990. Hepatic injury due to small bowel bacterial overgrowth in rats. Gastroenterology. 98:414423.

2. Lichtman, S. N., J. Keku, J. H. Schwab, and R. B. Sartor. 1991. Hepatic injury associated with small bowel bacterial overgrowth is prevented by metronidazole and tetracycline. Gastroenterology. 100:513-519.

3. Lichtman, S. N., J. Keku, J. H. Schwab, and R. B. Sartor. 1991. Evidence for peptidoglycan absorption in rats with experimental small bowel bacterial overgrowth. Infect. Immun. 59:555-562.

4. Lichtman, S. N., J. Keku, R. L. Clark, J. H. Schwab, and R. B. Sartor. 1991. Biliary tract disease in rats with experimental small bowel bacterial overgrowth. Hepatology. 13:766-772.

5. King, C. E., and P. P. Toskes. 1979. Small bowel bacterial overgrowth. Gastroenterology. 76:1035-1055.

6. Podda, M., C. Gzezzi, P. M. Battezzati, A. Crosignani, M. Zuin, and A. Roda. 1990. Effects of ursodeoxycholic acid and taurine on serum liver enzymes and bile acids in chronic hepatitis. Gastroenterology. 98:1044-1050.

7. Cohen, J., M. Aslam, C. D. Pusey, and C. J. Ryan. 1987. Protection from endotoxemia: a rat model of plasmaphoresis and specific adsorption with polymyxin B. J. Infect. Dis. 155:690-695.

8. Stimpson, S. A., J. H. Schwab, M. J. Janusz, S. K. Anderle, R. R. Brown, and W. J. Cromartie. 1986. Acute and chronic inflammation induced by peptidoglycan structures and polysaccharide complexes. In Biological Properties of Peptidoglycan. P. H. Seidl and K. H. Schleifer, editors. Walter de Gruyter, Berlin. 273-290.

9. Esser, R. E., J. H. Schwab, and R. A. Eisenberg. 1985. Immunology of peptidoglycan-polysaccharide polymers from cell walls of group A streptococci. In Immunology of the Bacterial Cell Envelope. D. E. S. Stewart-Tull and M. Davies, editors. John Wiley \& Sons Ltd., London. 91-118.

10. Wahl, S. M., D. A. Hunt, J. B. Allen, R. L. Wilder, L. Paglia, and A. R Hand. 1986. Bacterial cell wall induced hepatic granulomas. J. Exp. Med. 163:884-902.

11. Cromartie, W. J., J. G. Craddock, J. H. Schwab, S. K. Anderle, and C. H. Yang. 1977. Arthritis in rats after systemic injection of streptococcal cells or cell walls. J. Exp. Med. 146:1585-1602.

12. Wells, A., G. Pararajasegaram, M. Baldwin, C. H. Yang, M. Hammer, and A. Fox. 1986. Uveitis and arthritis induced by systemic injection of streptococcal cell walls. Invest. Ophthalmol. Visual Sci. 27:921-925.

13. Sartor, R. B., W. J. Cromartie, D. W. Powell, and J. H. Schwab. 1985. Granulomatous enterocolitis induced in rats by purified bacterial cell wall fragments. Gastroenterology. 89:587-595.

14. Stimpson, S. A., R. R. Brown, S. K. Anderle, D. G. Klapper, R. L. Clark, W. J. Cromartie, and J. H. Schwab. 1986. Arthropathic properties of cell wall polymers from normal flora bacteria. Infect. Immun. 51:240-251.

15. Severijnen, A. J., M. P. Hazenberg, and J. P. van de Merwe. 1989. Induction of chronic arthritis in rats by cell wall fragments of anaerobic coccoid rods isolated from the fecal flora of patients with Crohn's disease. Digestion. 39:118125.

16. Dalldorf, F. G., W. J. Cromartie, S. K. Anderle, R. L. Clark, and J. H. Schwab. 1980. The relation of experimental arthritis to the distribution of streptococcal cell wall fragments. Am. J. Pathol. 100:383-402.

17. Stimpson, S. A., R. A. Lerch, D. R. Cleland, D. P. Yarnell, R. L. Clark, W. J. Cromartie, and J. H. Schwab. 1987. Effect of acetylation on arthropathic activity of group A streptococcal peptidoglycan-polysaccharide fragments. Infect. Immun. 55:16-23.

18. Stimpson, S. A., R. E. Esser, W. J. Cromartie, and J. H. Schwab. 1986. Comparison of in vivo degradation of ${ }^{125}$ I-labeled peptidoglycan-polysaccharide fragments from group A and group D streptococci. Infect. Immun. 52:390-396.

19. Janusz, M. J., R. E. Esser, and J. H. Schwab. 1986. In vivo degradation of bacterial cell wall by the muralytic enzyme mutanolysin. Infect. Immun. 52:459467.

20. Yokogawa, K., S. Kawata, T. Takemura, and Y. Yoshimura. 1975. Purification and properties of lytic enzymes from Streptomyces globisporus 1829. Agric. Biol. Chem. 39:1533-1543.

21. Janusz, M. J., C. Chetty, R. A. Eisenberg, W. J. Cromartie, and J. H 
Schwab. 1984. Treatment of experimental erosive arthritis in rats by injection of the muralytic enzyme mutanolysin. J. Exp. Med. 160:136-1374.

22. Sartor, R. B., L. C. Holt, D. E. Bender, and J. H. Schwab. 1991. Prevention and treatment of chronic relapsing enterocolitis in rats by in vivo degration of bacterial cell polymers. Gastroenterology. 100:A613. (Abstr.)

23. Cameron, D. G., G. M. Watson, and L. J. Witts. 1949. The clinical association of macrocytic anemia with intestinal structure and anastomosis. Blood. 4:793-813.

24. Sherman, P., A. Wesley, and G. G. Forstner. 1985. Sequential disaccharidase loss in rat intestinal blind loops: impact of malnutrition. Am. J. Physiol. 248:G626-G632.

25. Wahl, S. M., J. B. Allen, S. Dougherty, V. Evequoz, R. L. Wilder, A. R. Hand, and L. M. Wahl. 1986. T lymphocyte-dependent evolution of bacterial cel wall-induced hepatic granulomas. J. Immunol. 137:2199-2209.

26. Berg, R. D. 1981. Promotion of the translocation of enteric bacteria from the gastrointestinal tracts of mice by oral treatment with penicillin, clindamycin or metronidazole. Infect. Immun. 33:854-861.

27. Stimpson, S. A., and J. H. Schwab. 1989. Chronic remittent erosive arthritis induced by bacterial peptidoglycan-polysaccharide structures. Pharm. Meth ods Control Inflammation. 5:381-394.

28. Voller, A., P. E. Bidwell, and A. Bartlett. 1976. Enzyme immunoassay in diagnostic medicine. Bull. WHO. 53:55-64.

29. Eisenberg, R., A. Fox, J. J. Greenblatt, S. K. Anderle, W. J. Cromartie, and J. H. Schwab. 1982. Measurement of bacterial cell wall in tissues by solid-phase radioimmunoassay: correlation of distribution and persistence with experimenta arthritis in rats. Infect. Immun. 38:127-135.

30. Knook, D. L., and E. C. Sleyster. 1976. Separation of Kupffer and endothelial cells of the rat liver by centrifugal elutriation. Exp. Cell Res. 99:444-449.

31. Fox, A., R. R. Brown, S. K. Anderle, C. Chetty, W. J. Cromartie, H Gooder, and J. H. Schwab. 1982. Arthropathic properties related to molecular weight of peptidoglycan-polysaccharide polymers of streptococcal cell walls. In fect. Immun. 35:1003-1010.

32. Poo, J. L., G. Feldmann, S. Erlinger, A. Braillon, C. Gaudin, M. Dumont, and D. Lebrec. 1992. Ursodeoxycholic acid limits liver histological alteration and portal hypertension induced by bile duct ligation in the rat. Gastroenterology 102:1752-1759.
33. Tamura, T., S. Kitamura, T. Krol, W. G. M. Hardison, and K. Miyai 1991. Effect of ursodeoxycholic acid on cholestatic liver injury in the rat. Gastroenterology. 100:A342. (Abstr.)

34. Greenblatt, J. J., N. Hunter, and J. H. Schwab. 1980. Antibody response to streptococcal cell wall antigens associated with experimental arthritis in rats. Clin. Exp. Immunol. 42:450-457.

35. Anderle, S. K., J. B. Allen, R. L. Wilder, R. A. Eisenberg, W. J. Cromartie, and J. H. Schwab. 1985. Measurement of streptococcal cell wall in tissues of rats resistant or susceptible to cell wall-induced chronic erosive arthritis. Infect. Immun. 49:836-837.

36. Lichtman, S. N., E. Okoruwa, R. T. Currin, and J. J. Lemasters. 1991 Kupffer cells have a role in hepatic injury associated with small bowel bacterial overgrowth. Hepatology. 14:168A. (Abstr.)

37. Schwab, J. H., S. K. Anderle, R. R. Brown, F. G. Dalldorf, and R. C. Thompson. 1991. Pro- and anti-inflammatory roles of interleukin-1 in recurrence of bacterial cell wall-induced arthritis in rats. Infect. Immun. 59:44364442.

38. McCall, R. D., J. S. Haskill, and R. B. Sartor. 1991. Interleukin-1 and IL-1 receptor antagonist gene expression correlate with activity of inflammation in spontaneously relapsing enterocolitis in rats. Gastroenterology. 100:A598. (Abstr.)

39. Dela Cadena, R. A., K. J. Laskin, R. A. Pixley, R. B. Sartor, J. H. Schwab, N. Back, G. S. Bedi, R. S. Fisher, and R. W. Colman. 1991. Role of kallikreinkinin system in pathogenesis of bacterial cell wall-induced inflammation. Am. J. Physiol. 260:G213-G219.

40. Lichtman, S. N., R. B. Sartor, and J. H. Schwab. 1988. Elimination of peptidoglycan-polysaccharide in rat bile. Gastroenterology. 94:A262. (Abstr.)

41. Sartor, R. B., T. M. Bond, and J. H. Schwab. 1988. Systemic uptake and intestinal inflammatory effects of luminal bacterial cell wall polymers in rats with acute colonic injury. Infect. Immun. 56:2101-2108.

42. Davis, S. W., L. C. Holt, and R. B. Sartor. 1990. Luminal bacteria and bacterial polymers potentiate indomethacin-induced intestinal injury in the rat. Gastroenterology. 98:A444. (Abstr.)

43. Sartor, R. B., D. E. Bender, and L. C. Holt. 1991. Differential intestinal inflammation with indomethacin in inbred rat strains. FASEB (Fed. Am. Soc. Exp. Biol.) J. 5:A1706. (Abstr.) 